\title{
STRATEGI PEMASARAN CPO (CRUDE PALM OIL) PADA PT. BIO NUSANTARA TEKNOLOGI BENGKULU TENGAH
}

\author{
Nurzam ${ }^{1}$ \\ E-mail : Nurzam@bio-nusantara.com \\ Efran Ahmat Wijaya ${ }^{2}$ \\ E-mail : Efran.wijaya@bio-nusantara.com \\ UNIVERSITAS DEHASEN BENGKULU
}

\begin{abstract}
The purpose of this study was to determine how the marketing strategy of CPO (Crude Palm Oil) at PT. Bio Nusantara Teknologi Bengkulu Tengah. Data collection methods used were interviews, documentation and questionnaires. The analytical methods used are SWOT, namely strength, weakness, opportunity and threat. Based on the results of research and data analysis, it can be concluded that the marketing strategy of PT. Bio Nusantara Teknologi Bengkulu Tengah is in quadrant I (first), meaning that PT. Bio Nusantara Teknologi Bengkulu Tengah is a SO strategy, which shows that this business has environmental opportunities and the many forces that encourage the use of these opportunities. This situation suggests a growth oriented strategy (expansion strategy).
\end{abstract}

Keywords: CPO (Crude Palm Oil), SWOT Analysis.

\section{PENDAHULUAN}

Minyak kelapa sawit atau Crude Palm Oil yang untuk selanjutnya disingkat CPO merupakan komoditas yang mempunyai nilai strategis. Salah satunya disebabkan karena CPO (Crude Palm Oil) merupakan bahan baku pembuatan minyak makan, sementara minyak makan merupakan salah satu dari sembilan kebutuhan pokok bangsa Indonesia. Permintaan akan minyak makan di dalam dan di luar negeri yang kuat dan terus meningkat merupakan indikasi pentingnya peranan komoditas kelapa sawit dalam perekonomian bangsa. Kebutuhan minyak nabati dan lemak dunia juga terus meningkat sebagai akibat dari pertumbuhan penduduk dan peningkatan pendapatan domestik bruto, agar kebutuhan tersebut terpenuhi maka pemerintah mendorong peningkatan pengusahaan kebun kelapa sawit (Pahan, 2008:17).

Dari berbagai perkembangan dan kajian yang ada, terlihat bahwa ke depan persaingan dalam usaha perkebunan kelapa sawit bukan saja terjadi antar sesama negara produsen melainkan juga persaingan dengan jenis minyak nabati lainnya. Seiring dengan peningkatan konsumsi CPO (Crude Palm Oil) di dalam maupun di luar negeri yang cukup tinggi, maka harus disertai dengan pengembangan seluruh subsitem agribisnisnya 
mulai dari hulu hingga hilir. Pemasaran hasil pertanian yang efektif dari hasil produksi kelapa sawit itu sendiri dapat memberikan nilai tambah yang lebih tinggi.

Indonesia merupakan sebuah negara kepulauan yang memiliki lahan potensial untuk pertanian. Salah satu komoditas pertanian yang dikembangkan di Indonesia adalah kelapa sawit. Kelapa sawit memiliki banyak keunggulan salah satunya adalah kedudukannya sebagai komoditas ekspor nasional. Permintaan kelapa sawit pun terus meningkat sejalan dengan perkembangan teknologi dalam mengolahnya. Hal tersebut mengakibatkan komoditas kelapa sawit terus dikembangkan dan perkebunannya terus di perluas. Salah satu usaha pemerintah dalam mengembangkan perkebunan sawit adalah memperluas lahan perkebunan, Pemerintah terus melaksanakan targetnya hingga laju perluasan kebun sawit kini sudah mencapai 800 ribu hektar per tahun (Asih Putri, 2010). Sampai dengan tahun 2018 sekarang, luas perkerbunan kelapa sawit yang ada di Indonesia mencapai 14,03 ha (Kompas.com).

Perkebunan di Provinsi Bengkulu dibagi menjadi 3 yaitu perkebunan rakyat, perkebunan negara dan perkebunan swasta. Luas perkebunan kelapa sawit 309.100 ha (BPS, 2017). Provinsi Bengkulu memiliki 9 Kabupaten dan 1 kota, salah satunya adalah Kabupaten Bengkulu Tengah. Setelah dibukanya perkebunan-perkebunan berskala besar dan dengan berdirinya pabrik sebagai pengolah hasil perkebuan dapat membuka wawasan bagi petani yang berdomisili di sekitar perkebunan tersebut, sehingga terciptalah perkebunan rakyat sebagai akibat positif dari teknologi yang dibawa oleh pembangunan pertanian perkebunan tersebut. Hal ini terbukti dari tidak tertampungnya lagi tandan buah segar (TBS), sebagai hasil produksi yang melonjak tajam dari membanjirnya perkebunan kelapa sawit rakyat. Tak dapat disangkal, minyak sawit telah menjadi tulang punggung ekonomi bagi sebagian besar rumah tangga di Provinsi Bengkulu karena banyak penggunaan lahan dan konversi komoditas diubah menjadi perkebunan kelapa sawit. (Sukiyono, dkk; 2017).

Bahan baku untuk membuat minyak sawit kasar (Crude Palm Oil) pada PT. Bio Nusantara Teknologi diperoleh dari kebun inti milik perusahaan dan juga berasal dari pihak ketiga yaitu plasma, mitra dan umum, namun yang hanya pemasok dari pihak ketiga yang mengikuti alur antrian, sedangkan pemasok dari kebun inti langsung masuk tanpa mengantri. Ada beberapa tahapan sistem penanganan yang dilakukan oleh perusahaan dalam proses penerimaan bahan baku. Untuk memasuki tahapan-tahapan tersebut para pemasok bahan baku harus mengikuti alur antrian agar dalam penanganan penerimaan ini berlangsung baik. Sehingga perusahaan harus memiliki pelayanan yang baik pula agar pihak pemasok bahan baku dapat dengan lancar pada saat penanganan penerimaan bahan baku. Pemasok bahan baku umum menjual bahan baku tersebut ke perusahaan biasanya tergantung harga yang ditawarkan oleh perusahaan. Pemasok mitra harus tetap menjual bahan baku ke perusahaan karena sudah ada ikatan kontrak. Pemasok plasma, buah yang dijual sudah harus sesuai dengan standarisasi perusahaan. Adanya perbedaan sumber pasokan bahan baku untuk pembuatan membuat minyak sawit kasar (Crude Palm Oil) ini memungkinkan terjadinya perbedaan penanganan penerimaan dan harga yang dilakukan oleh perusahaan. 
Strategi pemasaran merupakan salah satu alat untuk mencapai tujuan jangka panjang perusahaan. PT. Bio Nusantara Teknologi sebagai perusahaan yang mempunyai visi dan misi sudah seharusnya merumuskan strategi pemasaran yang tepat untuk usaha pemasaran minyak kelapa sawit. Persaingan yang semakin ketat dewasa ini menyebabkan tidak sedikit perusahaan yang gagal dan bangkrut karena ketidakmampuannya dalam merencanakan, mengorganisasikan, melaksanakan, dan mengendalikan stategi pemasaran secara tepat. Strategi pemasaran perusahaan juga harus memperhatikan hal-hal seperti, menganalisis peluang pasar, menyusun strategi pemasaran, merencanakan program pemasaran, dan mengkoordinasikan upaya pemasaran. Hal ini mencakup kegiatan seperti, mendefinisikan visi misi bisnis, menganalisis peluang dan ancaman eksternal, menganalisis kekuatan dan kelemahan internal, merumuskan masalah, merumuskan sasaran, merumuskan strategi, serta merumuskan program pendukungnya.

Strategi pemasaran yang perusahaan rancang sedemikian rupa sehingga dapat fleksibel, efisien, dan efektif dalam mencapai tujuan utamanya. Perusahaan harus memperhatikan unsur-unsur bauran pemasaran (marketing mix) seperti perencanaan produk, penentuan harga, tempat dan promosi yang dilakukan perusahaan tersebut. Fungsi pemasaran ini merupakan ujung tombak dalam menjalankan kegiatan usaha atau bisnis. Suatu rangkaian proses bisnis pada akhirnya membutuhkan pemasaran yang efisien. Penanganan yang profesional serta efektivitas dalam menjalankan strategi pemasaran itu sendiri akan berperan dan berpengaruh dalam menyalurkan serta menciptakan nilai suatu produk.

Strategi merupakan hal yang sangat penting bagi setiap perusahaan untuk mencapai keberhasilan organisasi. Setiap organisasi pasti memiliki strategi, meskipun strategi tersebut tidak pernah dirumuskan secara eksplisit. Hal ini dikarenakan, tidak ada satu perusahaan pun yang mempunyai sumber daya yang tidak terbatas. Sehingga para ahli strategi harus memutuskan strategi alternatif mana yang akan memberi keuntungan terbesar kepada perusahaan. Besarnya volume penjualan CPO (Crude Palm Oil) dari PT. Bio Nusantara Teknologi inilah yang membuat peneliti tertarik menjadikannya sebagai obyek penelitian, dan ingin mengetahui serta menganalisis strategi pemasaran seperti apa yang digunakan dalam menjalankan bisnis minyak kelapa sawit selama ini. Oleh sebab itu, penulis tertarik melakukan penelitian dengan judul "Strategi Pemasaran CPO (Crude Palm Oil) Pada PT. Bio Nusantara Teknologi Bengkulu Tengah”.

\section{TINJAUAN PUSTAKA}

\section{Pemasaran}

Pemasaran menarik perhatian yang sangat besar baik dari perusahaan, lembaga maupun antar bangsa. Berbagai organisasi dalam melaksanakan pemasaran seperti lembagalembaga pemerintah, organisasi keagamaan dan lain-lainnya memandang pemasaran sebagai suatu cara baru untuk berhubungan dengan masyarakat umum. Umumnya bagi negara-negara yang sedang berkembang, mempelajari dan berusaha untuk memperbaiki cara bersaing yang lebih baik dalam pemasaran dunia, baik dilakukan dengan cara penelitian ataupun promosi dalam usaha memasarkan dan mendistribusikan barangbarang produknya. 
Kotler dan Keller (2008:5) mengemukakan bahwa pemasaran adalah suatu fungsi organisasi dan serangkaian proses untuk menciptakan, mengomunikasikan, dan memberikan nilai kepada pelanggan dan untuk mengelola hubungan pelanggan dengan cara yang menguntungkan organisasi dan memangku kepentingannya.

Tjiptono (2008:7) memberikan definisi pemasaran sebagai suatu proses sosial dan manajerial dimana individu atau kelompok untuk mendapatkan apa yang mereka butuhkan dan inginkan melalui penciptaan, pewarnaan, dan pertukaran segala sesuatu yang bernilai dengan orang atau kelompok lain.Sedangkan Stanton yang dikutip Firdaus (2008:120) mengatakan bahwa pemasaran adalah suatu sistem keseluruhan dari kegiatan-kegiatan bisnis yang ditujukan untuk merencanakan dan menentukan harga, mempromosikan dan mendistribusikan barang atau jasa yang dapat memuaskan kebutuhan, baik kepada pembeli yang ada maupun pembeli potensial.

Penulis lain Machfoedz (2010:140) mengemukakan bahwa pemasaran adalah suatu proses yang diterapkan perusahaan untuk memenuhi kebutuhan dan keinginan konsumen dengan menyediakan produk (barang dan jasa). Konsumen tertentu yang merupakan sasaran upaya pemasaran disebut pasar sasaran. Kasali (2005:53) definisi pemasaran adalah pemasaran adalah suatu proses perencanaan dan eksekusi, mulai dari tahap konsepsi, penetapan harga, promosi, hingga distribusi barang-barang, ide-ide dan jasa-jasa, untuk melakukan pertukaran yang memuaskan individu dan lembagalembaganya.

\section{Strategi Pemasaran}

Setiap perusahaan mengarahkan kegiatan usahanya untuk dapat menghasilkan produk yang dapat memberikan kepuasan kepada konsumen sehingga dalam jangka waktu dan jumlah produk tertentu dapat diperoleh keuntungan seperti yang diharapkan. Melalui produk yang dihasilkannya, perusahaan menciptakan, membina dan mempertahankan kepercayaan langganan akan produk tersebut. Keberhasilan suatu perusahaan sangat ditentukan oleh ketepatan produsen dalam memberikan kepuasan kepada sasaran konsumen yang ditentukannya, dimana usaha-usaha pemasaran diarahkan kepada konsumen yang ditujukan sebagai sasaran pasarnya. Istilah strategi berasal dari bahasa Yunani yaitu strategi yang berarti seni atau ilmu untuk menjadi seorang Jenderal. Konsep strategi militer seringkali digunakan dan diterapkan dalam dunia bisnis yang mengikuti lingkungan yang dipilih dan merupakan pedoman untuk mengalokasikan sumber daya dan usaha suatu perusahaan (Tjiptono, 2008:42).

Tjiptono (2008:43), menyatakan bahwa strategi pemasaran adalah rencana yang hendak diikuti oleh manajer pemasaran. Rencana tindakan ini didasarkan atas analisa situasi dan tujuan-tujuan perusahaan dan merupakan cara untuk pencapaian tujuan tersebut. Dalam pengertian strategi seringkali terkandung perencanaan merupakan proses yang berlangsung secara terus- menerus dalam suatu perusahaan. Oleh sebab itu strategi pemasaran dari setiap perusahaan merupakan rencana yang menyeluruh dimana perusahaan berharap mencapai sasaran yang telah ditentukan, yang pada akhirnya untuk merealisasikan tujuan dari perusahaan yang bersangkutan. 
Menurut Kotler (2004:57) menyatakan bahwa perencanaan strategis yang berorientasi pasar adalah proses manajerial untuk mengembangkan dan menjaga agar tujuan, keahlian, dan sumber daya organisasi sesuai dengan peluang pasar yang terus berubah dengan tujuan membentuk dan menyempurnakan usaha dan produk perusahaan sehingga memenuhi target laba dan pertumbuhan. Sedangkan menurut Assauri (2008:168) strategi pemasaran adalah serangkaian tujuan dan sasaran, kebijakan dan aturan yang memberi arah kepada usaha-usaha pemasaran perusahaan dari waktu ke waktu, pada masing-masing tingkatan dan acuan serta alokasinya, terutama sebagai tanggapan perusahaan dalam menghadapi lingkungan dan keadaan persaingan yang selalu berubah, Oleh karena itu, penentuan strategi pemasaran harus didasarkan atas analisa lingkungan dan internal perusahaan melalui analisa keunggulan dan kelemahan perusahaan, serta analisa kesempatan dan ancaman yang dihadapi perusahaan dari lingkungannya.

\section{Bauran Pemasaran (Marketing Mix)}

Marketing mix atau bauran pemasaran adalah kombinasi variabel atau kegiatan yang merupakan inti dari sistem pemasaran, variabel mana dapat dikendalikan oleh perusahaan untuk mempengaruhi reaksi para pembeli atau konsumen. Jadi marketing mix terdiri dari himpunan variabel yang dapat dikendalikan dan digunakan oleh perusahaan untuk mempengaruhi tanggapan konsumen dalam pasar sasarannya. Variabel atau kegiatan tersebut perlu dikombinasikan dan dikoordinasikan oleh perusahaan seefektif mungkin dalam melakukan tugas atau kegiatan pemasarannya. Dengan demikian, perusahaan tidak hanya sekadar memiliki kombinasi kegiatan yang terbaik saja, akan tetapi dapat mengkoordinasikan berbagai variabel marketing mix tersebut untuk melaksanakan program pemasaran secara efektif. Marketing mix adalah variabel-variabel pemasaran yang terdiri, produk (product), harga (price), distribusi atau penempatan produk (place), dan promosi (promotion) (Tjiptono, 2008:30).

Tjiptono (2008:30), mengemukakan bahwa bauran pemasaran merupakan separangkat alat yang dapat digunakan pemasar untuk membentuk karakteristik jasa yang ditawarkan kepada pelanggan. Gitosudarmo (2008:182) mengatakan bahwa bauran pemasaran atau marketing mix merupakan alat yang dapat dipergunakan oleh pengusaha untuk mempengaruhi konsumennya. Jadi marketing mix terdiri dari himpunan variabel yang dapat dikendalikan dan digunakan oleh perusahaan untuk mempengaruhi tanggapan konsumen dalam pasar sasarannya.

\section{Lingkungan Bisnis}

Bisnis dan perusahaan sebagai suatu sistem akan berkait dengan sekumpulan faktor tertentu yang dapat mempengaruhi arah dan kebijakan perusahaan dalam mengelola bisnisnya. Menurut Umar (2005:78), lingkungan bisnis dapat dibagi atas dua lingkungan, yaitu lingkungan internal dan lingkungan eksternal. Lingkungan internal merupakan aspek-aspek yang ada di dalam perusahaan (Umar, 2005:80). Lingkungan eksternal dibagi ke dalam dua kategori, yaitu lingkungan luar dan lingkungan industri (Umar, 2005:82). 


\section{CPO (Crude Palm Oil)}

CPO (Crude Palm Oil) atau minyak kelapa sawit adalah minyak nabati edibel yang didapatkan dari mesocarp buah pohon kelapa sawit, umumnya dari spesies elaeis guineensis dan sedikit dari spesies Elaeis oleifera dan Attalea maripa (Reeves, 1979).

Minyak sawit kasar (Crude Palm Oil) merupakan minyak kelapa sawit mentah yang diperoleh dari hasil ekstraksi atau dari proses pengempaan daging buah kelapa sawit dan belum mengalami pemurnian. Minyak sawit biasanya digunakan untuk kebutuhan bahan pangan, industri kosmetik, industri kimia, dan industri pakan ternak. Kebutuhan minyak sawit sebesar 90\% digunakan untuk bahan pangan seperti minyak goreng, margarin, shortening, pengganti lemak kakao dan untuk kebutuhan industri roti, cokelat, es krim, biskuit, dan makanan ringan. Kebutuhan $10 \%$ dari minyak sawit lainnya digunakan untuk industri oleokimia yang menghasilkan asam lemak, fatty alcohol, gliserol, dan metil ester serta surfaktan (Pahan, 2008:50).

\section{Analisis SWOT}

Analisis SWOT adalah identifikasi berbagai faktor secara sistematis untuk merumuskan strategi perusahaan. Analisis ini didasarkan pada logika yang dapat memaksimalkan kekuatan (strengts) dan peluang (opportunities), namun secara bersamaan dapat meminimalkan kelemahan (weakness) dan ancaman (threats) (Rangkuti, 2004:18).

Dalam membuat keputusan perusahaan perlu pertimbangan faktor internal yang mencakup kekuatan dan kelemahan maupun faktor eksternal yang mencakup peluang dan ancaman. Dalam hal ini analisis SWOT dipakai jika para penentu strategi perusahaan mampu melakukan pemaksimalan peranan faktor kekuatan dan memanfaatkan peluang sekaligus berperan sebagai alat untuk meminimalisi kelemahan yang terdapat dalam tubuh organisasi dan menekan ancaman yang timbul dan harus dihadapi dengan tepat. Adapun dapat kita lihat diagram analisis SWOT sebagai berikut : Gambar 1. Diagram Analisis SwOT

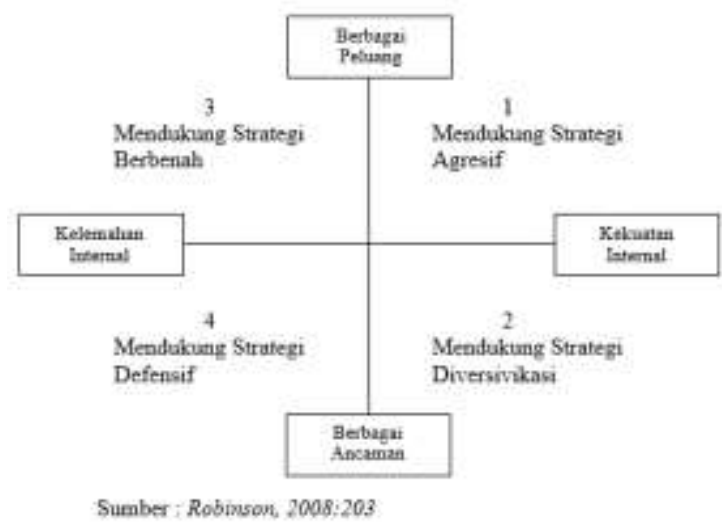

\section{Analisis Lingkungan Eksternal}

Lingkungan eksternal menunjukkan peluang dan ancaman yang dimiliki oleh perusahaan agar perusahaan dapat membat strategi yang tepat sehingga dapat mengambil keuntungan dari peluang serta meminimalisir kerugian yang disebabkan oleh ancaman. Analisis terhadap lingkungan eksternal dapat membantu perusahaan untuk memiliki visi dan misi yang jelas serta mampu untuk mencapai tujuan jangka 
panjang. Kekuatan eksternal dapat dibedakan menjadi lima kategori (David, 2009:89) yaitu:

1. Kekuatan Ekonomi Aspek ini berhubungan tentang kondisi ekonomi di tempat perusahaan sedang menjalankan kegiatan. Kondisi perkonomian mempengaruhi iklim bisnis suatu perusahaan melalui permasalahan-permasalahan ekonomi seperti perubahan suku bunga, inflasi, kenaikan upah tenaga kerja dan lain sebagainya. Dalam menghadapi inflasi perusahaan-perusahaan akan kesulitan karena semakin meningkatnya harga-harga bahan baku sehingga perusahaan memerlukan strategi agar permasalahan-permasalah dari kondisi ekonomi dapat dihadapi.

2. Kekuatan Sosial, Budaya, Demografi, dan Lingkungan Perubahan pada aspek ini akan memiliki pengaruh yang besar terhadap kebanyakan produk barang dan jasa yang dihasilkan perusahaan. Faktor sosial, budaya dan lingkungan yang mempengaruhi perusahaan adalah keyakinan, sikap, nilai dan opini yang berkembang serta gaya hidup orang-orang yang berada di lingkungan eksternal perusahaan. Trend baru pun menjadi salah satu contoh dari aspek sosial, budaya dan lingkungan yang dapat menciptakan tipe baru dalam konsumen yang mengakibatkan kebutuhan akan barang dan jasa menjadi meningkat, menurun, maupun berubah. Seperti kondisi yang menyudutkan industri kelapa sawit karena perusahaan kelapa sawit dianggat memberikan dampak buruk bagi lingkungan. Dalam hal ini perusahaan- perusahaan khususnya perusahaan kelapa sawit harus mampu beradaptasi dan merubah pandangan-pandangan tersebut ke arah yang lebih baik.

3. Kekuatan Politik, Pemerintah dan Hukum Beberapa faktor yang termasuk kedalam aspek ini diantaranya adalah stabilitas keamanan, regulasi, situasi politik dan lain sebagainya. Pemerintah merupakan pihak yang paling berperan karena merupakan pihak yang membuat aturan-aturan. Pemerintah dengan berbagai aturan-aturan yang dikeluarkannya memberikan regulasi bagi perusahaan kelapa sawit dalam menjalankan bisnisnya agar tercipta kondisi yang kondusif. Industri kelapa sawit yang merupakan salah satu penyumbang devisa negara akan terus menjadi sorotan pemerintah dalam pengembangannya.

4. Kekuatan Teknologi

Teknologi saat ini berkembang dengan sangat cepat. Dengan adanya teknologi maka akan memudahkan perusahaan dalam meningkatkan produksi serta mendistribusikan produk ke konsumen dengan cepat dan tepat. Perkembangan teknologi membantu perusahaan untuk terus berinovasi demi mencapai efisiensi dalam kegiatan produksi yang bertujuan untuk meningkatkan produksi dari perkebunan kelapa sawit.

5. Kekuatan Kompetitif

Kekuatan kompetitif perusahaan dirumuskan oleh Porter dalam "Konsep Kekuatan Bersaing Porter" yang terdapat dalam David (2009:86). Kekuatan kompetitif perusahaan dapat dilihat berdasarkan:

a) Persaingan antar perusahaan

Dalam suatu industri terdapat banyak perusahaan-perusahaan yang bersaing untuk memperoleh keuntungan. Perusahaan harus memiliki keunggulan dibandingkan pesaingnya dalam menjalankan usaha. keunggulan-keunggulan perusahaan ini dapat dimunculkan melalui penetapan strategi perusahaan yang bertujuan untuk memenangkan persaingan dalam industri. Perubahan strategi pada suatu perusahan 
mungkin akan mendapat serangan balasan berupa penurunan harga, peningkatan kualitas produk, melakukan inovasi produk dan penyediaan jasa dan lain-lain.

b) Masuknya pendatang baru.

Pendatang baru pada suatu industri membawa kapasitas baru dan keinginan untuk merebut pangsa pasar yang telah ada. Akibatnya harga menjadi turun sehingga mengurangi laba yang diterima. Utnuk mengurangi ancaman masuknya pendatang baru ke dalam indusrtri diperlukan hambatan-hambatan masuk di antaranya terkait dengan teknologi dan penguasaan khusus, pengalaman, preferensi merek, tingkat kesetiaan konsumen digabung dengan reaksi para pesaing yang sudah ada sehingga dapat dipikirkan oleh pendatang baru.

c) Adanya produk substitusi.

Industri akan bersaing dengan industri produk pengganti dalam merebut pasar yang akan membatasi laba potensial industri. Produk pengganti yang perlu mendapatkan perhatian lebih besar adalah produk lain yang menjalankan fungsi yang sama atau produk yang mempunyai kecenderungan memilki harga atau prestasi yang lebih baik dari produk lainnya.

d) Kekuatan tawar-menawar penjual

Kekuatan tawar menawar pemasok bertujuan untuk melihat sejauh mana kebutuhan pemasok dalam mempengaruhi industri melalui kenaikan harga, pengurangan kualitas produk yang dipasok dan peran produk yang dipasok bagi pelanggan. Pemasok dikatakan memiliki daya tawar menawar yang kuat bila tidak adanya produk pengganti lain yang dijual kepada industri. Produk pemasok merupakan input penting bagi suatu bisnis, industri bukan merupakan pelanggan yang penting bagi kelompok pemasok dan produk pemasok terdeferensiasi atau pemasok telah menciptakan biaya peralihan.

e) Kekuatan tawar menawar pembeli

Pembeli merupakan tujuan akhir dari produk suatu industri. Pembeli bersaing dengan industri dengan memaksa harga turun, tawar menawar untuk mutu yang lebih tinggi dan pelayanan yang lebih baik, serta berperan sebagai pesaing satu sama lain dan semua akan berpengaruh pada pengorbanan industri.

Adapun beberapa kekuatan dari PT. Bio Nusantara Teknologi Bengkulu Tengah antara lain :

1. Adanya Job Description yang jelas.

2. Penerapkan prinsip minyak sawit lestari (sustainable palm oil).

3. Tingkat produktivitas $\mathrm{CPO}$ perusahaan yang tinggi.

4. Pencatatan data keuangan dan administrasi yang sudah terkomputerisasi.

5. Sistem informasi dan komunikasi yang memadai.

6. Kualitas CPO yang bermutu tinggi.

7. Penggunaan bahan baku yang berkualitas.

8. Manajemen keuangan/pengeluaran biaya yang efisien.

9. Memiliki laboratorium riset sendiri.

10. Koordinasi yang kuat antar divisi.

11. Sistem kontrol dilakukan secara konsisten. 
Adapun beberapa kelemahan dari PT. Bio Nusantara Teknologi Bengkulu Tengah antara lain :

1. Sistem penyimpanan data yang terpisah antara kantor pusat dengan perkebunan.

2. Tidak memiliki cluster pengolahan produk turunan untuk diversifikasi produk hilir.

3. Luas lahan perkebunan yang tergolong kecil.

4. Teknologi pabrik pengolahan yang masih tertinggal dengan pesaing.

5. Penjualan ekspor CPO masih batas ke pembeli dalam negeri.

\section{Analisis Lingkungan Internal}

Analisis terhadap lingkungan internal perusahaan akan menggambarkan kekuatan dan kelemahan yang dimiliki perusahaan. Dengan mengetahui kekuatan dan kelemahan dari perusahaan perusahaan diharapkan mampu untuk meminimalisir kerugian-kerugian yang dapat terjadi akibat kelemahan yang dimiliki perusahaan dengan cara menutupinya dengan kekuatan yang dimiliki oleh perusahaan (David, 2009:90). Ada beberapa faktorfaktor yang dapat dianalisis antara lain:

a) Manajemen

Manajemen merupakan suatu tingkatan sistem pengaturan organisasi yang mencakup sistem produksi, pemasaran, pengelolaan sumberdaya manusia dan keuangan. Fungsi dari manajemen itu sendiri dapat diterapkan pada struktur organisasi perusahaan secara keseluruhan yaitu perencanaan, pengorganisasian, pemotivasian, penunjukan staff serta pengendalian. Proses manajemen di dalam suatu perusahaan menentukan keberhasilan suatu perusahaan dalam mencapai tujuan yang diharapkan. Kondisi manajemen yang baik akan membantu kinerja perusahaan menjadi lebih baik dalam menjalankan kegiatan bisnis.

b) Pemasaran

Pemasaran merupakan proses menetapkan, mengantisipasi, menciptakan dan memenuhi kebutuhan dan keinginan pelanggan akan produk dan jasa. Kegiatan pemasaran dilakukan agar perusahaan mampu bersaing dengan perusahaan lain dalam memperoleh pelanggan sehingga perusahaan mampu menguasai pasar. proses pemasaran terdiri dari dari bauran pemasaran yaitu produk, harga, tempat dan promosi (4P). Kegiatan pemasaran yang baik dapat membantu perusahaan dalam menguasai pasar dan meningkatkan penjualan yang akhirnya akan membantu perusahaan dalam memperoleh keuntungan.

c) Keuangan

Aspek ini merupakan aspek sensitive karena menyangkut dengan keuangan, namun aspek ini sangat penting untuk dianalisis. Keuangan merupakan ukuran tunggal terbaik posisi kompetitif perusahaan dan merupakan salah satu daya tarik bagi pihak investor. Faktor-faktor yang perlu diperhitungkan adalah kemampuan perusahaan mengatur modal jangka pendek dan jangka panjang, beban yang harus dipikul sebagai upaya memperoleh modal tambahan, hubungan baik dengan penanam modal, pengelolaan keuangan, struktur modal kerja, harga jual produk, dan sistem akuntansi yang handal.

d) Produksi

Semua kegiatan yang mengubah bahan baku/input menjadi suatu barang atau jasa disebut sebagai produksi. Aspek ini juga terkait dengan manajemen produksi yang berhubungan langsung dengan input, transformasi dan output. Dalam kegiatan 
produksi perusahaan juga harus memperhatikan keinginan konsumen sehingga produk yang dihasilkan mampu diterima oleh konsumen.

e) Penelitian dan Pengembangan

Penelitian dan pengembangan biasanya diarahkan pada penciptaan produk-produk atau teknologi baru sebelum pesaing melakukannya. Hal tesebut dilakukan untuk meningkatkan pemasaran serta mendapatkan keunggulan dari biaya melalui efisiensi. Perusahaan yang menjalankan strategi pengembangan produk khususnya harus memiliki orientasi penelitian dan pengembangan yang kuat (David 2009).

Adapun beberapa peluang dari PT. Bio Nusantara Teknologi Bengkulu Tengah antara lain :

1. Keadaan lahan dan iklim yang cocok untuk tanaman kelapa sawit.

2. Peningkatan jumlah populasi dunia dan berkembangnya trend pemakaian bahan dasar oleochemical sehingga meningkatkan permintaan produk kelapa sawit.

3. Perkembangan teknologi budidaya dan pengolahan tanaman kelapa sawit.

4. Tingkat loyalitas pembeli yang tinggi terhadap perusahaan.

5. Produk substitusi kelapa sawit yang belum efisien.

Adapun beberapa ancaman dari PT. Bio Nusantara Teknologi Bengkulu Tengah antara lain :

1. Banyaknya perusahaan baru yang masuk ke industri kelapa sawit.

2. Pencurian buah dan perebutan lahan dengan masyarakat sekitar.

3. Perda tingkat kabupaten/kota dan provinsi yang tidak sejalan dengan pengembangan bisnis.

4. Kondisi cuaca yang tidak menentu sehingga mempengaruhi kegiatan produksi.

5. Nilai tukar rupiah yang melemah.

6. Harga jual CPO yang fluktuatif.

\section{Perumusan Alternatif Strategi}

Matriks IFE dan EFE (Tahap Pengumpulan Data) Matriks IFE digunakan untuk mengevaluasi faktor-faktor internal untuk melihat kekuatan dan kelemahan utama perusahaan terhadap fungsi-fungsi bisnisnya, Data dan informasi aspek internal perusahaan dapat digali dari beberapa fungsional perusahaan, misalnya dari aspek manajemen, keuangan, SDM, pemasaran. Matriks EFE digunakan untuk mengevaluasi faktor-faktor eksternal perusahaan. Data eksternal dikumpulkan untuk menganalisa halhal menyangkut persoalan ekonomi, sosial, budaya, lingkungan, politik, pemerintahan, hukum, teknologi, persaingan di pasar industri di mana perusahaan berada. Hal ini penting karena faktor eksternal berpengaruh secara langsung maupun tidak langsung terhadap perusahaan.

Pada prinsipnya tahapan kerja IFE matriks sama dengan EFE matriks. Langkah-langkah tahapan kerja IFE dan EFE Matriks sebagai berikut:

1. Buat daftar critical success factors (CSF) untuk aspek internal yang mencakup kekuatan dan kelemahan bagi perusahaan dan untuk aspek eksternal mencakup peluang dan ancaman.

2. Tentukan bobot (weight) dari CSF tadi dengan skala yang lebih tinggi bagi yang 
berprestasi tinggi dan begitu pula sebaliknya. Jumlah seluruh bobot harus sebesar 1 .

3. Tentukan rating setiap CSF antara 1 sampai 5, dimana : $1=$ kelemahan utama atau ancaman utama, 2 = kelemahan kecil atau Ancaman kecil,3 = keadaan yang seimbang diantara kelemahan dan kekuatannya, $4=$ kekuatan kecil atau peluang kecil, 5 = kekuatan utama atau peluang utama. Rating ditentukan berdasarkan efektivitas strategi perusahaan. Dengan demikian, nilainya didasarkan pada kondisi perusahaan.

4. Kalikan nilai bobot dengan nilai rating-nya untuk mendapatkan skor semua CSF.

5. Jumlahkan semua skor untuk mendapatkan skor total bagi perusahaan yang dinilai.

6. Matriks IE (penentuan posisi perusahaan), matriks IE merupakan pemetaan dari hasil matriks IFE dan EFE pada tahap pengumpulan data dan menempatkan perusahaan pada salah satu kondisi di dalam sembilan sel.

Analisis SWOT (Tahap Pencocokan). Analisis SWOT adalah identifikasi berbagai faktor secara sistematis untuk merumuskan strategi perusahaan. Analisis ini didasarkan pada logika yang dapat memaksimalkan kekuatan (strengths) dan peluang (opportunities) serta dapat meminimalkan kelemahan (weakness) dan ancaman (threats). Asumsi dasar dari analisis tersebut dalah bahwa kinerja perusahaan dalam suatu industri ditentukan oleh kombinasi faktor internal dan eksternal perusahaan (Rangkuti, 2004:30). Analisis SWOT dilakukan dengan membandingkan faktor internal dan eksternal sebagai logika dasar penyusunan strategi dalam memaksimalkan kekuatan yang dimiliki perusahaan untuk memanfaatkan kekuatan dan peluang yang ada, dan pada saat yang bersamaan meminimalkan kelemahan dan ancaman yang dihadapi oleh perusahaan. Matriks ini menghasilkan empat kemungkinan alternatif strategi yaitu strategi S-O, strategi W-O, strategi S-T dan strategi W-T.

\section{Penelitian Terdahulu}

Berdasarkan hasil penelitian dan analisa data tentang strategi pemasaran pada PT. Bio Nusantara Teknologi Bengkulu Tengah yang di analisis menggunakan SWOT, maka dapat ditarik suatu kesimpulan bahwa :

1. Strategi pemasaran PT. Bio Nusantara Teknologi Bengkulu Tengah berada pada kuadran I (kesatu), artinya PT. Bio Nusantara Teknologi Bengkulu Tengah strategi SO, yang menunjukkan usaha ini memiliki peluang lingkungan dan banyaknya kekuatan yang mendorong dimanfaatkannya peluang tersebut. Situasi ini menyarankan strategi yang berorientasi pada pertumbuhan (growth oriented strategy/expansion strategy).

2. Berdasarkan analisis matrik SWOT diperoleh alternatif strategi pemasaran PT. Bio Nusantara Teknologi Bengkulu Tengah sebagai berikut :

\section{Strategi SO}

a. Tekstur produk yang lembut membuat masyarakat semakin percaya dengan kualitas produk yang ditawarkan.

b. Menambah lagi jumlah keragaman produk serta mempertahankan harga produk yang murah agar pelanggan baru menjadi pelanggan yang loyal.

c. Memperluas pangsa pasar. 
d. Memanfaatkan kemajuan teknologi dan informasi dalam melakukan promosi produk agar lebih terarah.

2. Strategi ST

a. Meningkatkan pelayanan agar pelanggan merasa puas dan loyal.

b. Mengembangkan daya saing.

3. Strategi WO

a. Lebih banyak berinovasi dalam menambah varian rasa dan bentuk produk.

b. Membuat tampilan produk semenarik mungkin sehingga konsumen tertarik untuk membeli.

c. Memajang semua produk show case agar konsumen mengenal semua produk yang dijual.

d. Menambah lagi jumlah kuantitas produk agar barangnya menjadi tidak terbatas.

4. Strategi WT

a. Melakukan cek pasar terhadap pesaing dan membuat penyesuaian harga yang bersaing dengan harga pasar.

b. Menjalin hubungan baik dengan pelanggan.

\section{METODE PENELITIAN}

\section{Jenis Penelitian}

Jenis penelitian yang digunakan oleh penulis adalah deskriptif analisis. Menurut Supranto (2002:36), deskriptif analisis adalah penelitian yang bertujuan untuk menguraikan karakteristik (sifat-sifat) tentang suatu keadaan pada waktu tertentu. Dalam penelitian ini berusaha melakukan penelitian untuk mendapatkan data secara akurat dan nyata, kemudian data tersebut dibahas dan diuraikan secara sistematis sehingga diperoleh suatu kesimpulan.

\section{Definisi Operasional}

a. Strength (kekuatan) adalah kompetensi khusus yang memberikan keunggulan komparatif bagi PT. Bio Nusantara Teknologi Bengkulu Tengah.

b. Weakness (kelemahan) adalah kekurangan atau keterbatasan dalam hal sumber daya yang ada pada PT. Bio Nusantara Teknologi Bengkulu Tengah baik itu keterampilan atau kemampuan yang menjadi penghalang bagi kinerjanya.

c. Opportunity (peluang) adalah berbagai hal dan situasi yang menguntungkan bagi PT. Bio Nusantara Teknologi Bengkulu Tengah.

d. Threat (ancaman) adalah faktor-faktor lingkungan yang tidak menguntungkan bagi PT. Bio Nusantara Teknologi Bengkulu Tengah.

\section{Metode Pengumpulan Data}

Pengumpulan data dilakukan dengan pengamatan langsung di lapangan, wawancara, kuisioner, laporan-laporan dan data-data penunjang milik perusahaan, bahan pustaka dari penelitian sebelumnya serta artikel-artikel rujukan. Selain itu pengambilan data juga diambil melalui wawancara dengan pihak internal perusahaan yaitu karyawan dari perusahaan untuk ini. Data sekunder mengenai gambaran umum perusahaan mencakup data tentang sejarah perkembangan perusahaan, lokasi perusahaan, visi dan misi 
perusahaan, struktur organisasi perusahaan serta pemasaran produk. Data-data tersebut diperoleh dari laporan dan berkas yang bersangkutan yang dimiliki perusahaan, wawancara dan pengamatan langsung di lapangan. Kemudian selanjutnya data diolah menggunakan skala likert (skala 1-5) seperti berikut :

Skor 1 = sangat tidak setuju

Skor 2 = tidak setuju

Skor 3 = kurang setuju

Skor $4=$ setuju

Skor 5 = sangat setuju

\section{Metode Pengambilan Sampel}

Menurut Sugiyono (2010:115), populasi adalah wilayah generalisasi yang terdiri atas objek atau subjek yang mempunyai kualitas dan karakteristik tertentu yang ditetapkan oleh peneliti untuk dipelajari dan kemudian ditarik kesimpulan, dalam penelitian ini populasinya adalah seluruh karyawan PT. Bio Nusantara Teknologi Bengkulu Tengah sedangkan sampel adalah bagian dari jumlah karakteristik yang dimiliki oleh populasi tertentu, sampel dalam penelitian ini adalah karyawan yang berhubungan dengan penelitian yang menjadi subjek pada PT. Bio Nusantara Teknologi Bengkulu Tengah.

Dalam penelitian ini sampel yang diambil menggunakan teknik sampel insidental, dimana sampel insidental ini merupakan penentuan sampel berdasarkan kebetulan siapa saja yang secara kebetulan/insidental bertemu dengan peneliti dan orang tersebut memiliki kecocokan sebagai sumber data Sugiyono (2010:125). Sampel yang diambil dalam penelitian ini terdiri dari 15 orang karyawan pada PT. Bio Nusantara Teknologi Bengkulu Tengah dan 5 orang dari masing-masing perusahaan yang pernah dan masih menjadi klien pada PT. Bio Nusantara Teknologi Bengkulu Tengah.

\section{Metode Analisis}

Untuk mengetahui strategi yang dilakukan PT. Bio Nusantara Teknologi Bengkulu Tengah dilakukan analisis SWOT. Secara khusus model analisis SWOT yang akan digunakan dalam penelitian ini yaitu (Rangkuti, 2004:31) :

\section{Tabel 1. Matrik SWOT}

\begin{tabular}{|l|l|l|}
\hline \multirow{2}{*}{ EFAS IFAS } & STRENGTHS (S) & WEAKNESSES (W) \\
\cline { 2 - 3 } & $\begin{array}{l}\text { Tentukan 5-10 Faktor } \\
\text { Kekuatan Internal }\end{array}$ & $\begin{array}{l}\text { Tentukan 5-10 Faktor } \\
\text { Kelemahan Internal }\end{array}$ \\
\hline OPPORTUNITIES (O) & STRATEGI (SO) & STRATEGI (WO) \\
\hline $\begin{array}{l}\text { Tentukan 5-10 Faktor } \\
\text { Peluang Eksternal }\end{array}$ & $\begin{array}{l}\text { Ciptakan strategi yang } \\
\text { menggunakan kekuatan } \\
\text { untuk memanfaatkan } \\
\text { peluang }\end{array}$ & $\begin{array}{l}\text { Ciptakan strategi yang } \\
\text { meminimalkan kelemahan } \\
\text { untuk memanfaatkan } \\
\text { peluang }\end{array}$ \\
\hline THREATS (T) & STRATEGI (ST) & STRATEGI (WT) \\
\hline Tentukan 5-10 Faktor & $\begin{array}{l}\text { Ciptakan strategi yang } \\
\text { menggunakan kekuatan } \\
\text { Ancaman Eksternal }\end{array}$ & $\begin{array}{l}\text { Ciptakan strategi yang } \\
\text { meminimalkan kelemahan } \\
\text { dan menghindari ancaman }\end{array}$ \\
\hline
\end{tabular}

Sumber : Rangkuti, 2004.

a. IFAS (internal strategic factory analysis summary) dengan kata lain faktor-faktor strategis internal suatu perusahaan disusun untuk merumuskan faktor-faktor internal 
dalam kerangka strength dan weakness. Adapun IFAS dan EFAS dihitung bobot dan ratingnya berdasarkan Tabel 2 berikut ini :

Tabel 2. Alternatif Jawaban Responden Terhadap IFAS dan EFAS

\begin{tabular}{|c|l|c|c|}
\hline No & \multicolumn{1}{|c|}{ Alternatif Jawaban } & Bobot & Rating \\
\hline 1 & STS (sangat tidak setuju) & 0,10 & 1 \\
\hline 2 & TS (tidak setuju) & 0,25 & 2 \\
\hline 3 & KS (kurang setuju) & 0,50 & 3 \\
\hline 4 & S (setuju) & 0,75 & 4 \\
\hline 5 & SS (sangat setuju) & 1,00 & 5 \\
\hline
\end{tabular}

b. EFAS (eksternal strategic factory analysis summary) dengan kata lain faktor-faktor strategis eksternal suatu perusahaan disusun untuk merumuskan faktor-faktor eksternal dalam kerangka opportunities and threats.

c. Strategi SO

Strategi ini dibuat berdasarkan jalan pikiran perusahaan, yaitu memanfaatkan seluruh kekuatan untuk merebut dan memanfaatkan peluang sebesar-besarnya.

d. Strategi ST

Strategi ini dibuat menggunakan kekuatan yang dimiliki perusahaan untuk mengatasi ancaman

e. Strategi WO

Strategi ini diterapkan berdasarkan pemanfaatan peluang yang ada dengan cara meminimalkan kelemahan yang ada.

f.Strategi WT

Strategi ini digunakan pada kegiatan yang bersifat defensif dan berusaha meminimalkan kelemahan yang ada serta menghindari ancaman.

\section{HASIL PENELITIAN DAN PEMBAHASAN}

Faktor Internal

\begin{tabular}{|l|c|c|c|}
\hline \multicolumn{1}{|c|}{ Keterangan } & Bobot & Rating & $\begin{array}{c}\text { Skor } \\
\text { (bobot } \mathbf{~} \\
\text { rating) }\end{array}$ \\
\hline 1. Adanya job description yang jelas & 0,88 & 5 & 4 \\
\hline $\begin{array}{l}\text { 2. Penerapan prinsip minyak sawit lestari } \\
\text { (sustainable palm oill) }\end{array}$ & 0,80 & 4 & 3 \\
\hline $\begin{array}{l}\text { 3. Tingkat produktivitas CPO perusahaan } \\
\text { yang tinggi }\end{array}$ & 0,88 & 5 & 4 \\
\hline $\begin{array}{l}\text { 4. Pencatatan data keuangan dan } \\
\text { administrasi yang sudah terkomputerisasi }\end{array}$ & 0,85 & 4 & 3 \\
\hline $\begin{array}{l}\text { 5. Sistem informasi dan komunikasi yang } \\
\text { memadai }\end{array}$ & 0,88 & 5 & 4 \\
\hline 6. Kualitas CPO yang bermutu tinggi & 0,89 & 5 & 4 \\
\hline $\begin{array}{l}\text { 7. Penggunaan bahan baku yang } \\
\text { berkualitas }\end{array}$ & 0,78 & 4 & 3 \\
\hline $\begin{array}{l}\text { S. Manajemen keuangan/pengeluaran biaya } \\
\text { yang efisien }\end{array}$ & 0,78 & 4 & 3 \\
\hline 9. Memiliki laboratorium riset sendiri & 0,85 & 4 & 3 \\
\hline 10.Koordinasi yang kuat antar divisi & 0,88 & 5 & 4 \\
\hline $\begin{array}{l}\text { 11.Sistem kontrol dilakukan secara } \\
\text { konsisten }\end{array}$ & 0,88 & 5 & 4 \\
\hline
\end{tabular}

Sumber : Hasil penelitian dan diolah, 2019.

a. Adanya job description yang jelas

Job Description yang jelas akan membantu para pegawai untuk bekerja sesuai dengan kelebihan di bidangnya masing-masing. Hal ini menjadikan masing-masing 
pegawai di perusahaan memiliki tugas yang jelas sehingga pekerjaan mampu diselesaikan secara efisien.

b. Penerapan prinsip minyak sawit lestari (sustainable palm oil)

Penerapan sistem minyak sawit lestari membantu perusahaan dalam meningkatkan produksi dan kualitas dari produk yang mereka hasilkan. Dengan adanya sistem ini perusahaan dituntut untuk melakukan kegiatan bisnis sesuai dengan standar yang ditetapkan. Dalam pelaksanaannya perusahaan diawasi oleh pihak internal maupun eksternal agar seluruh aktivitas perusahaan tetap memenuhi standar yang sudah ditetapkan. Penerapan sistem ini juga mempengaruhi harga jual produk yang dihasilkan perusahaan karena kualitas dari produk yang dihasilkan memiliki standar yang tinggi.

c. Tingkat produktivitas $\mathrm{CPO}$ perusahaan yang tinggi

PT. Bio Nusantara Teknologi Bengkulu Tengah merupakan salah satu perusahaan perkebunan kelapa sawit dengan tingkat produktivitas tertinggi di Provinsi Bengkulu. Tingkat produktivitas yang tinggi ini dihasilkan dari kegiatan pengolahan yang dilakukan dengan teknologi yang sudah modern. Selain itu penggunaan bahan baku yang berkualitas mampu membantu perusahaan untuk meningkatkan produksi CPO yang akan dihasilkan. Produktivitas CPO socfindo sebesar 5.74 ton/ha jauh lebih tinggi dibandingkan produktivitas CPO nasional yang hanya sebesar 3.7 ton/ha.

d. Pencatatan data keuangan dan administrasi yang sudah terkomputerisasi

PT. Bio Nusantara Teknologi Bengkulu Tengah dalam pecatatan data keuangan dan administrasinya sudah menggunakan sistem, hal ini dikarenakan untuk membuat kerja para karyawan lebih efektif dan efisien sehingga meminimalisasi terjadinya kesalahan yang mungkin akan terjadi.

e. Sistem informasi dan komunikasi yang memadai

Perusahaan memiliki fasilitas informasi dan komunikasi yang baik sehingga pekerjaan disetiap divisi ataupun antar divisi yang berbeda dapat berjalan secara efisien.

f. Kualitas CPO yang bermutu tinggi

Penerapan sistem minyak sawit lestari (RSPO) yang mengharuskan perusahaan memiliki prosedur pengolahan yang berstandar tinggi dengan sistem kontrol yang konsisten menjadikan CPO yang dihasilkan oleh PT. Bio Nusantara Teknologi Bengkulu Tengah memiliki kualitas dengan mutu yang tinggi.

g. Penggunaan bahan baku yang berkualitas

Bahan baku pengolahan berupa TBS mampu mempengaruhi tingkat ekstraksi CPO yang dihasilkan. TBS yang dihasilkan oleh PT. Bio Nusantara Teknologi Bengkulu Tengah memiliki kualitas yang baik disebabkan oleh pengelolaan kebun yang dilakukan socfindo memikiki prosedur yang baik ditambah lagi penggunaan bibit sendiri yang mampu membantu meningkatkan produksi TBS yang dihasilkan.

h. Manajemen keuangan atau pengeluaran biaya yang efisien

Dalam melakukan pengelolaan keuangan perusahaan memiliki pengawasan yang ketat sehingga setiap pengeluaran yang dilakukan oleh perusahaan dapat dipertanggung jawabkan. Selain dengan pengawasan yang baik perusahaan juga memiliki perencanaan yang matang dari setiap kegiatan yang dilakukan sehingga pengeluaran perusahaan dialokasikan secara efisien. 
i. Memiliki laboratorium riset sendiri

Dalam melakukan penelitian yang berkaitan dengan efisiensi dan efektivitas pemanfaatan seluruh komponen kelapa sawit, maka perusahaan memiliki laboratorium riset sendiri.

j. Sistem kontrol dilakukan secara konsisten

Sistem kontrol yang dimiliki oleh perusahaan ini dilakukan secara berkala dari lini terkecil sampai dengan lini terbesar, hal ini dimaksudkan agar semua kegiatan yang ada di dalam perusahaan dilaksanakan sesuai dengan standar operasional prosedurnya.

\begin{tabular}{|l|c|c|c|}
\hline \multicolumn{1}{|c|}{ Keterangan } & Bobot & Rating & $\begin{array}{c}\text { Skor (bobot x } \\
\text { rating) }\end{array}$ \\
\hline $\begin{array}{l}\text { 1. Sistem penyimpanan data yang } \\
\text { terpisah antara kantor pusat dengan } \\
\text { perkebunan }\end{array}$ & 0,39 & 3 & 1 \\
\hline $\begin{array}{l}\text { 2. Tidak memiliki cluster pengolahan } \\
\text { produk turunan untuk diversifikasi } \\
\text { produk hilir }\end{array}$ & 0,51 & 3 & 2 \\
\hline $\begin{array}{l}\text { 3.Luas lahan perkebunan yang } \\
\text { tergolong kecil }\end{array}$ & 0,40 & 3 & 1 \\
\hline $\begin{array}{l}\text { 4.Teknologi pabrik pengolahan yang } \\
\text { masih tertinggal dengan pesaing }\end{array}$ & 0,40 & 3 & 1 \\
\hline $\begin{array}{l}\text { 5.Penjualan CPO masih batas ke } \\
\text { pembeli dalam negeri }\end{array}$ & 0,51 & 3 & 2 \\
\hline
\end{tabular}

Sumber : Hasil penelitian dan diolah, 2019.

a. Sistem penyimpanan data yang terpisah antara kantor pusat dengan perkebunan

Terpisahnya sistem penyimpanan data antara kantor pusat dengan perkebunan sering menimbulkan masalah dalam pemindahan beberapa data. Hal ini menjadi kendala karena aktivitas perusahaan akan tersendat untuk beberapa waktu.

b. Tidak memiliki cluster pengolahan produk turunan untuk diversifikasi produk hilir Masih minimnya pengembangan perusahaan ke sektor hilir menjadi permasalahan perusahaan dalam meningkatkan pendapatan perusahaan. Laba perusahaan akan sangat terpengaruh oleh harga jual CPO yang tidak dapat ditentukan sendiri sehingga saat harga jual CPO sedang rendah perusahaan akan mengalami penurunan laba yang diperoleh.

c. Luas lahan perkebunan yang tergolong kecil

Kecilnya lahan yang dimiliki oleh perusahaan sangat mempengaruhi tingkat produksi yang dihasilkan. PT. Bio Nusantara Teknologi Bengkulu Tengah hanya memiliki luas areal perkebunan sebesar 3.926 ha yang terpakai dari kepemilikan Hak Guna Usaha (HGU) sebesar 6.000 ha, masih jauh dibandingkan beberapa pesaing yang sudah memiliki areal perkebunan lebih dari 100 ribu ha.

d. Teknologi pabrik pengolahan yang masih tertinggal dengan pesaing

Banyaknya pesaing yang sudah mengembangkan perusahaannya ke sektor hilir menyebabkan perkembangan teknologi pabrik pengolahan menjadi lebih maju. Pengembangan pabrik pengolahan ini belum mampu diikuti oleh PT. Bio Nusantara Teknologi Bengkulu Tengah sehingga perusahaan kesulitan dalam mengembangkan kegiatan ke sektor hilir, hal ini dikarenakan laboratorium riset yang dimiliki oleh PT. Bio Nusantara Teknologi Bengkulu Tengah masih baru dan masih terus perlu dikembangkan lagi.

e. Penjualan CPO masih batas ke pembeli dalam negeri 
PT. Bio Nusantara Teknologi Bengkulu Tengah masih melakukan pemasaran CPO mereka sebatas ke pembeli dalam negeri saja, belum ada ekspensi pemasaran untuk mencari pembeli luar negeri.

\section{Faktor Eksternal}

\begin{tabular}{|l|c|c|c|}
\hline \multicolumn{1}{|c|}{ Keterangan } & Bobot & Rating & $\begin{array}{c}\text { Skor (bobot } x \\
\text { rating) }\end{array}$ \\
\hline $\begin{array}{l}\text { 1. Keadaan lahan dan iklim yang cocok } \\
\text { untuk tanaman kelapa sawit }\end{array}$ & 17,25 & 4 & 3 \\
\hline $\begin{array}{l}\text { 2. Peningkatan jumlah populasi dunia } \\
\text { dan berkembangnya trend pemakaian } \\
\text { bahan dasar oleochemical sehingga } \\
\text { meningkatkan permintaan produk } \\
\text { kelapa sawit. }\end{array}$ & 15,75 & 4 & 3 \\
\hline $\begin{array}{l}\text { 3. Perkembangan teknologi budidaya } \\
\text { dan pengolahan tanaman kelapa } \\
\text { sawit }\end{array}$ & 17,25 & 4 & 3 \\
\hline $\begin{array}{l}\text { 4. Tingkat loyalitas pembeli yang tinggi } \\
\text { terhadap perusahaan. }\end{array}$ & 17,5 & 5 & 4 \\
\hline $\begin{array}{l}\text { 5. Produk substitusi kelapa sawit yang } \\
\text { belum efisien }\end{array}$ & 17,75 & 5 & 4 \\
\hline
\end{tabular}

Sumber : Hasil penelitian dan diolah, 2019.

a. Keadaan lahan dan iklim yang cocok untuk tanaman kelapa sawit

Keadaan lahan dan iklim di Bengkulu Tengah memang memiliki kecocokan yang baik untuk tanaman kelapa sawit. Kecocokan lahan dan iklim mampu meningkatkan tingkat produksi CPO yang dihasilkan perusahaan. Hal ini menjadi peluang bagi perusahaan untuk terus meningkatkan produksi CPO mereka.

b. Peningkatan jumlah populasi dunia dan berkembangnya trend pemakaian bahan dasar oleochemical sehingga meningkatkan permintaan produk kelapa sawit.

Terus meningkatnya populasi dunia akan meningkatkan kebutuhan untuk produk kelapa sawit dalam memenuhi kebutuhan sehari-hari. Perubahan pola bahan baku untuk industri pengolahan makanan, kosmetik, dan bahan bakar ke produk kelapa sawit yang dinilai lebih efisien dan ramah lingkungan semakin meningkatkan permintaan akan produk olahan kelapa sawit. Peningkatan permintaan ini menjadi peluang bagi perusahaan untuk mampu meningkatkan produksi untuk memenuhi kebutuhan yang tinggi sehingga tingkat penjualan produk akan meningkat.

c. Perkembangan teknologi budidaya dan pengolahan tanaman kelapa sawit

Perkembangan teknologi akan mempercepat suatu proses atau kegiatan sehingga proses tersebut dapat dikerjakan dengan lebih efisien. Penemuan-penemuan teknologi baru dalam budidaya dan pengolahan akan mampu meningkatkan produktivitas perusahaan dalam menghasilkan produk. Perusahaan harus terus memanfaatkan peluang dari terus berkembangnya teknologi agar mampu melakukan kegiatan produksi lebih efisien.

d. Tingkat loyalitas pembeli yang tinggi terhadap perusahaan

Kepercayaan pembeli terhadap PT. Bio Nusantara Teknologi Bengkulu Tengah semakin meningkat dengan adanya sertifikasi ISPO (Indonesian Sustainble Palm Oil) dan juga konsumen PT. Bio Nusantara Teknologi Bengkulu Tengah merupakan konsumen yang langsung melakukan kontrak dengan jumlah besar. 
e. Produk substitusi kelapa sawit yang belum efisien

Produk kelapa sawit memiliki produk substitusi berupa minyak kedelai, minyak bunga matahari, dan minyak jagung. Namun dari segi efisiensi produk kelapa sawit memiliki tingkat efisiensi yang jauh lebih tinggi dibandingkan produk substitusinya. Beberapa keunggulan dari minyak kelapa sawit antara lain relatif lebih tahan lama disimpan, tahan terhadap tekanan dan suhu tinggi, tidak cepat bau, memiliki kandungan gizi yang relatif tinggi, serta bermanfaat sebagai bahan baku berbagai jenis industri. Hal ini menjadikan permintaan terhadap produk kelapa sawit akan lebih tinggi dibanding dengan produk substitusinya.

\begin{tabular}{|c|c|c|c|}
\hline Keterangan & Bobot & Rating & $\begin{array}{c}\text { Skor } \\
\text { (bobot } \mathbf{x} \\
\text { rating) }\end{array}$ \\
\hline $\begin{array}{c}\text { 1.Banyaknya perusahaan baru yang } \\
\text { masuk ke industri kelapa sawit }\end{array}$ & 10 & 3 & 2 \\
\hline $\begin{array}{c}\text { 2.Pencurian buah dan perebutan lahan } \\
\text { dengan masyarakat sekitar }\end{array}$ & 10,75 & 3 & 2 \\
\hline $\begin{array}{c}\text { 3.Perda tingkat kabupaten/kota dan } \\
\text { provinsi yang tidak sejalan dengan } \\
\text { pengembangan bisnis }\end{array}$ & 12 & 3 & 2 \\
\hline $\begin{array}{c}\text { 4. Kondisi cuaca yang tidak menentu } \\
\text { sehingga mempengaruhi kegiatan } \\
\text { produksi }\end{array}$ & 10 & 3 & 2 \\
\hline 5.Nilai tukar rupiah yang melemah & 11,25 & 3 & 2 \\
\hline
\end{tabular}

Sumber : Hasil penelitian dan diolah, 2019.

a. Banyaknya perusahaan baru yang masuk ke industri kelapa sawit

Semakin banyaknya perusahaan sejenis yang masuk ke industri kelapa sawit akan menyebabkan persaingan di dalam industri semakin ketat. Perusahaan harus terus berkembang dengan melakukan inovasi-inovasi agar mampu terus bersaing di dalam industri kelapa sawit. Pencurian buah dan perebutan lahan dengan masyarakat sekitar.

Areal perkebunan yang dimiliki perusahaan selalu berbatasan dengan pemukiman penduduk di daerah tersebut sehingga seringkali terjadi gesekan antara pihak perusahaan dengan masyarakat. Masalah yang sering terjadi yaitu pencurian buah oleh oknum dari daerah sekitar kebun dan juga adanya klaim dari masyarakat tentang kepemilikan lahan yang digunakan perusahaan untuk perkebunan. Hal ini akan menjadi ancaman karena gangguan-gangguan tersebut akan mempengaruhi kinerja perusahaan terutama di daerah perkebunan.

b. Perda tingkat kabupaten/kota dan provinsi yang tidak sejalan dengan pengembangan bisnis.

Pemberlakuan otonomi daerah menjadikan banyaknya peraturan-peraturan berbeda disetiap daerah. Peraturan-peraturan yang ada di daerah seringkali menyulitkan perusahaan dalam melaksanakan kegiatan bisnis seperti penetapan pajak berganda ataupun dalam hal pembelian lahan yang dipersulit. Peraturan daerah yang menyulitkan seperti ini akan menjadi ancaman bagi perusahaan karena perusahaan akan semakin terhambat dalam melakukan kegiatan bisnis.

c. Kondisi cuaca yang tidak menentu sehingga mempengaruhi kegiatan produksi Kondisi cuaca yang tidak menentu yang disebabkan oleh efek rumah kaca menjadi ancaman yang harus dihadapi oleh perusahaan. Kondisi cuaca yang tidak menentu 
akan mempengaruhi pertumbuhan tanaman kelapa sawit sehingga produksi yang dihasilkan oleh tanaman akan menurun. Penerapan sistem budidaya yang tepat harus dilakukan oleh perusahaan agar proses produksi dapat berjalan dengan baik walaupun kondisi cuaca sedang tidak mendukung.

d. Nilai tukar rupiah yang melemah

Melemahnya nilai tukar rupiah terhadap mata uang asing akan menyebabkan peningkatan biaya yang harus dikeluarkan oleh perusahaan untuk memenuhi kebutuhan produksi. Harga pupuk, obat-obatan, atau mesin yang harus impor akan meningkat sehingga pengeluaran perusahaan akan meningkat. Selain itu melemahnya nilai tukar rupiah akan menurunkan daya beli masyarakat sehingga penjualan dari perusahaan akan menurun.

e. Harga jual CPO yang fluktuatif

Harga jual CPO yang berfluktuatif disebabkan harga jual CPO dipengaruhi harga produk lain seperti minyak bumi. CPO yang merupakan produk substitusi dari minyak bumi akan mengalami penurunan harga ketika harga minyak bumi sedang rendah. Harga jual CPO yang tidak dapat ditentukan perusahaan ini menyebabkan perusahaan harus mampu menyesuaikan biaya produksi dengan harga jual CPO. Hal ini menjadi ancaman utama karena ketika harga jual CPO menurun drastis perusahaan akan mengalami kerugian jika biaya produksi tidak mampu disesuaikan dengan harga jual CPO tersebut.

\section{Analisis Matriks SWOT}

\begin{tabular}{|c|c|c|}
\hline EFAS & $\begin{array}{l}\text { STRENGTHS (S) } \\
\text { 1.Adanya job description yang jelas } \\
\text { 2.Penerapkam prinsip minyak sawit lestari } \\
\text { (sustainable palm oil) } \\
\text { 3.Tingkat produktivitas CPO perusahaan } \\
\text { yang tinggi } \\
\text { 4.Pencatatan data keuangan dan administrasi } \\
\text { yang sudah terkomputerisasi } \\
\text { 5.Sistem informasi dan komunikasi yang } \\
\text { memadai } \\
\text { 6.Kualitas CPO yang bermutu tinggi } \\
\text { 7.Penggunaan bahan baku yang berkualitas } \\
\text { 8.Manajemen keuangan/pengeluaran biaya } \\
\text { yang efigien } \\
\text { 9.Memiliki laboratorium riset sendiri } \\
\text { 10.Koordinasi yang kuat antar divisi } \\
\text { 11. Sistem kontrol dilakukan secara } \\
\text { konsisten }\end{array}$ & $\begin{array}{l}\text { WE.AKNESSES (W) } \\
\text { 1.Sistem penyimpanan data yang terpisah } \\
\text { antara kantor pusat dengan perkebunan } \\
2 \text {.Tidak memiliki cluster pengolahan } \\
\text { produk turunan untuk diversifikasi produk } \\
\text { hilir } \\
\text { 3. Luas lahan perkebunan yang tergolong } \\
\text { kecil } \\
\text { 4. Teknologi pabrik pengolahan yang } \\
\text { masih tertinggal dengan pesaing } \\
5 \text {. Penjualan CPO masih bats ke pembeli } \\
\text { dalam negeri }\end{array}$ \\
\hline OPPORTUNITIES (O) & STRATEGI (SO) & STRATEGI (WO) \\
\hline $\begin{array}{l}\text { 1. Keadaan lahan dan iklim yang } \\
\text { cocok untuk tanaman kelapa sawit. } \\
\text { 2.Peninglcatan jumlah populasi } \\
\text { dunia dan berkembangnya trend } \\
\text { pemakaian bahan dasar } \\
\text { oleochemical sehingga } \\
\text { meningkatkan permintaan produk } \\
\text { kelapa samit } \\
\text { 3.Perkembangan teknologi } \\
\text { budidaya dan pengolahan tanaman } \\
\text { kelapa gawit } \\
\text { 4. Tingkat loyalitas pembeli yang } \\
\text { tinggi terhadap perusahaan } \\
\text { 5.Produk substitusi kelapa sawit } \\
\text { yang belum efisien }\end{array}$ & $\begin{array}{l}\text { 1. Melakukcan pengecelcan gecara berkala } \\
\text { terhadap pelkerjaan yang telah dibebankan } \\
\text { kepada para karyawan. } \\
\text { 2.Dengan memiliki ISPO (Indonesian } \\
\text { Sustainble Palm Oil) maka kualitas CPO } \\
\text { akan gemakin baik dan terpercaya } \\
\text { 3.Menguprage penggumaan program data } \\
\text { agar memudahkan karyawan dalam } \\
\text { menyajikan data terbaik } \\
\text { 4.Mengecek secara berkala berkaitan dengan } \\
\text { bahan bakau yang digunakan } \\
\text { 5.Memakcimalkan laboratorium riset yang } \\
\text { dimiliki }\end{array}$ & $\begin{array}{l}\text { 1.Meskipun penyimpanam data terpigah } \\
\text { tetapi pengecekan data dengan keadaan } \\
\text { lapangan yang ada harus secara berkala } \\
\text { dilakukcan. } \\
\text { 2.karena sudah mempunyai labortorium } \\
\text { sendiri kedepannya diharapkan agar dapat } \\
\text { melakukcan inovasi dalam hal produk } \\
\text { tambaham yang memiliki nilai material } \\
\text { 3.Hak guna usaha yang dimiliki } 6000 \mathrm{ha} \\
\text { tetapi yang baru dimanfaatkan sekitar } \\
\text { 3926ha, oleh karena itu harus lebih } \\
\text { memaksimalkcan penggunaan lahan lagi } \\
\text { 4.Tim pemasaran harus memaksimalkan } \\
\text { penjualan dengan mencoba mencari } \\
\text { peluang dalam pasar luar negeri }\end{array}$ \\
\hline THREATS (T) & STRATEGI (ST) & STRATEGI (WT) \\
\hline $\begin{array}{l}\text { 1. Bany aknya perusahaan baru yang } \\
\text { masuk ke industri kelapa sawit } \\
\text { 2.Pencurian buah dan perebutan } \\
\text { lahan dengan masyarakat gekcitar } \\
\text { 3.Perda tinglcat kabupaten/kota dan } \\
\text { provinai yang tidak sejalan dengan } \\
\text { pengembangan bisnis } \\
\text { 4. Kondisi cuaca yang tidak } \\
\text { menentu sehingga mempengaruhi } \\
\text { kegiatan produksi } \\
\text { 5.Nilai tukar rupiah yang melemah } \\
\text { 6. Harga jual CPO yang fluktuatif }\end{array}$ & $\begin{array}{l}\text { 1. Dengan banyaknya pesaing maka kualitas } \\
\text { dan kuantitas serta jenis produk harus } \\
\text { ditingkatkan agar konsumen tidak berpindah } \\
\text { ke pihak lain } \\
\text { 2. Memalksimalkan penjagaan aset yang } \\
\text { dimiliki perusahaan dengan berbagai macan } \\
\text { cara untuk mencegah terjadinya kehilangan }\end{array}$ & $\begin{array}{l}\text { 1.Dengan memiliki lini produk lain maka } \\
\text { akan mensubtitusi untung dan rugi } \\
\text { perusahaan berkaitan dengan perda serta } \\
\text { kondisi cuaca maupun nilai tukar rupiah } \\
\text { dan harga CPO yang fluktuatif }\end{array}$ \\
\hline
\end{tabular}

Sumber : PT. Bio Nusantara Teknologi Bengkulu Tengah, 2019. 


\section{Diagram Analisis SWOT}

Pada hasil analisis data yang diperoleh, menunjukkan bahwa PT. Bio Nusantara Teknologi Bengkulu Tengah dalam lingkungan internal berada pada posisi kekuatan (strenght) dinyatakan dengan skor sebesar 49 yang didapat dari nilai total matriks IFE dan dalam lingkungan eksternal berada pada posisi peluang (opportunities) dinyatakan dengan skor sebesar 29 yang didapat dari nilai total matriks EFE, sehingga dapat disimpulkan bahwa posisi diagram SWOT pada PT. Bio Nusantara Teknologi Bengkulu Tengah berada pada posisi 1 (satu) yaitu strategi SO, yang menunjukkan usaha ini memiliki peluang lingkungan dan banyaknya kekuatan yang mendorong dimanfaatkannya peluang tersebut. Situasi ini menyarankan strategi yang berorientasi pada pertumbuhan (growth oriented strategy/expansion strategy).

\section{PEMBAHASAN}

\section{Strategi SO}

a. Melakukan pengecekan secara berkala terhadap pekerjaan yang telah dibebankan kepada para karyawan. Dengan melakukan tindakan ini maka perusahaan telah membuat karyawannya bekerja secara displin, dengan adanya disiplin yang baik dari para karyawan maka hasil kerja karyawannya akan semakin berkualitas.

b. Dengan memiliki ISPO (Indonesian Sustainble Palm Oil) maka kualitas CPO akan semakin baik dan terpercaya. Dengan sertifikasi yang sudah dimiliki oleh PT. Bio Nusantara Teknologi Bengkulu Tengah maka konsumen yang sudah ada dan calon kosumen akan menjadi semakin percaya terhadap kualitas CPO yang dimiliki oleh PT. Bio Nusantara Teknologi Bengkulu Tengah.

c. Menguprage penggunaan program data agar memudahkan karyawan dalam menyajikan data terbaik. Semakin canggih program yang digunakan maka akan semakin mempermudah kerja karyawan pada PT. Bio Nusantara Teknologi Bengkulu Tengah sehingga hal ini akan meminimalkan kesalahan yang terjadi pada perusahaan dan mengurangi kerugian yang mungkin terjadi serta bisa memantau kerja karyawan dengan lebih efektif dan efisien lagi.

d. Mengecek secara berkala berkaitan dengan bahan baku yang digunakan. Bahan baku merupakan hal pokok yang harus diperhatikan oleh PT. Bio Nusantara Teknologi Bengkulu Tengah, karena jika bahan baku yang digunakan tidak berkualitas maka akan membuat hasil produk apapun dalam produksi PT. Bio Nusantara Teknologi Bengkulu Tengah itu sendiri tidak bagus pula, sehingga akan merugikan PT. Bio Nusantara Teknologi Bengkulu Tengah itu sendiri pada akhirnya.

e. Memaksimalkan laboratorium riset yang dimiliki. Ketika sudah memiliki laboratorium riset sendiri maka PT. Bio Nusantara Teknologi Bengkulu Tengah harus memaksimalkan potensi-potensi baru terhadap olahan dari bahan baku kelapa sawit dan tidak hanya bergantung pada satu jenik produk saja.

\section{Strategi ST}

a. Dengan banyaknya pesaing maka kualitas dan kuantitas serta jenis produk harus ditingkatkan agar konsumen tidak berpindah ke pihak lain. Pesaing merupakan hal yang wajar terjadi untuk setiap perusahaan yang ada, dengan adanya pesaing maka akan meningkatkan kewaspadaan perusahaan dan memaksimalkan kinerja perusahaan agar laba dan penjualan perusahaan tidak menurun, hal ini justru akan 
membuat perusahaan melakukan ekstensifikasi produk baru ataupun berbagai macan strategi lainnya dalam rangka untuk tetap bertahan di tengah semua persaingan pasar.

b. Memaksimalkan penjagaan aset yang dimiliki perusahaan dengan berbagai macam cara untuk mencegah terjadinya kehilangan. Pencurian mungkin akan dapat terjadi jika penjagaan terhadap aset tidak dimaksimalkan hal ini ditunjang pula dengan luasnya areal perkebunan yang dimiliki oleh PT. Bio Nusantara Teknologi Bengkulu Tengah, oleh karena itu perusahaan harus menggunakan berbagai macam strategi baru, misalnya dengan penggunaan cctv di berbagai wilayah dan pengecekan secara berkala untuk setiap harinya di jam-jam yang rawan akan terjadinya pencurian.

\section{Strategi WO}

a. Meskipun penyimpanan data terpisah tetapi pengecekan data dengan keadaan lapangan yang ada harus secara berkala dilakukan. Tidak ada alasan akan adanya perbedaan data kantor dengan kenyataan yang ada di lapangan apabila semua tugas sudah dilakukan dengan baik oleh semua karyawan. Oleh karena itu pemaksimalan kinerja karyawan pada PT. Bio Nusantara Teknologi Bengkulu Tengah harus lebih ditingkatkan lagi.

b. Karena sudah mempunyai labortorium sendiri kedepannya diharapkan agar dapat melakukan inovasi dalam hal produk tambahan yang memiliki nilai material. Penambahan lini produk baru dengan adanya laboratorium sebagai tempat eksperimen akan sangat berpengaruh pada kelangsungan hidup perusahaan di masa yang akan datang, hal ini dintunjang dengan banyaknya faktor yang mungkin terjadi berkaitan dengan regulasi maupun hal-hal yang mungkin akan terjadi di masa depan.

c. Hak guna usaha yang dimiliki 6000 ha tetapi yang baru dimanfaatkan sekitar 3926 ha, oleh karena itu harus lebih memaksimalkan penggunaan lahan lagi. Masih ada sekitar 2.074 ha lahan yang belum dimanfaatkan oleh PT. Bio Nusantara Teknologi Bengkulu Tengah, apabila PT. Bio Nusantara Teknologi Bengkulu Tengah bisa memanfaatkan hak guna usaha (HGU) lahan yang dimiliki untuk membuat diversifikasi produk lain ataupun penambahan areal kelapa sawit maka hal ini akan sangat berpengaruh terhadap perkembangan perusahaan di masa yang akan datang.

d. Tim pemasaran harus memaksimalkan penjualan dengan mencoba mencari peluang dalam pasar luar negeri. PT. Bio Nusantara Teknologi Bengkulu Tengah harus menggalakkan tim pemasaran yang mereka miliki, karena dengan pemasaran yang baik maka penjualan pada PT. Bio Nusantara Teknologi Bengkulu Tengah akan meningkat, tim pemasaran harus benar-benar cerdas dalam membaca pasar yang ada agar dapat memaksimalkan penjualan semua produk pada PT. Bio Nusantara Teknologi Bengkulu Tengah.

\section{Strategi WT}

Dengan memiliki lini produk lain maka akan mensubtitusi untung dan rugi perusahaan berkaitan dengan perda serta kondisi cuaca maupun nilai tukar rupiah dan harga CPO yang fluktuatif. Setiap perusahaan pasti akan mengalami untuk dan rugi, hal ini adalah suatu hal yang wajar, tetapi itulah gunanya karyawan di dalam perusahaan, dimana karyawan akan memaksimalkan kinerjanya dalam rangka untuk meningkatkan keberlangsungan hidup perusahaan, tidak hanya dalam jangka pendek tetapi jangka panjang pula, mengantisipasi hal-hal yang mungkin memperburuk kinerja perusahaan. 


\section{KESIMPULAN}

Berdasarkan hasil penelitian dan analisis SWOT, maka dapat disimpulkan bahwa :

1. Strategi pemasaran PT. Bio Nusantara Teknologi Bengkulu Tengah berada pada kuadran I (kesatu), artinya PT. Bio Nusantara Teknologi Bengkulu Tengah strategi SO, yang menunjukkan usaha ini memiliki peluang lingkungan dan banyaknya kekuatan yang mendorong dimanfaatkannya peluang tersebut. Situasi ini menyarankan strategi yang berorientasi pada pertumbuhan (growth oriented strategy/expansion strategy).

2. Hasil analisis data yang diperoleh, menunjukkan bahwa PT. Bio Nusantara Teknologi Bengkulu Tengah dalam analisis lingkungan internal berada pada posisi kekuatan (strength) dinyatakan dengan skor sebesar 49 yang didapat dari nilai total matriks IFE.

3. Hasil analisis data yang diperoleh, menunjukkan bahwa PT. Bio Nusantara Teknologi Bengkulu Tengah dalam analisis lingkungan eksternal berada pada posisi peluang (opportunities) dinyatakan dengan skor sebesar 29 yang didapat dari nilai total matriks EFE.

\section{SARAN}

Selama melaksanakan penelitian tersebut, maka penulis memberikan saran kepada PT. Bio Nusantara Teknologi Bengkulu Tengah yaitu :

1. Dalam rencana untuk meningkatkan volume penjualan, maka PT. Bio Nusantara Teknologi Bengkulu Tengah harus memaksimalkan penggunaan hak guna usaha (HGU) yang dimiliki oleh PT. Bio Nusantara Teknologi Bengkulu Tengah.

2. Manfaatkan tingkat sumber daya manusia yang dimiliki oleh PT. Bio Nusantara Teknologi Bengkulu Tengah secara optimal.

3. Manfaatkan teknologi informasi yang canggih dengan sebaik-baiknya agar volume penjualan semakin meningkat.

\section{DAFTAR PUSTAKA}

Assauri, Sofjan. 2008. Manajemen Pemasaran. Edisi Satu, Cetakan Kedelapan. Jakarta PT. Raja Grafindo Pusada.

Badan Pusat Statistik. 2017. Statistik Perkebunan Provinsi Bengkulu. Dinas Perkebunan Provinsi Bengkulu.

David, FR. 2009. Strategic Management: Manajemen Strategi Konsep. Edisi kedua belas. Jakarta: Salemba Empat.

Firdaus, Muhammad. 2008. Manajemen Agribisnis. Jakarta : Bumi Aksara.

Hunger JD, Wheelen TL. 2003. Manajemen Strategis. Agung J, penerjemah; Yogyakarta: Andi. Terjemahan dari : Strategic Management 5th Edition.

Gitosudarmo, Indriyo. 2008. Manajemen Pemasaran. Edisi kedua, cetakan pertama. Yogyakarta : BPFE. 
Kasali, Rhenal. 2005. Membidik Pasar Indonesia, Segmentasi, Targeting Dan Positioning. Edisi ketiga, cetakan ketujuh. Jakarta : Gramedia Pustaka Utama.

Kotler Philip. 2004. Manajemen Pemasaran : Analisis Perencanaan, Implementasi, dan Pengendalian. Jakarta : Prenhanlindo.

Kotler, Philip, dan Kevin Lane Keller. 2008. Manajemen Pemasaran. Edisi ketiga belas. Jakarta : Erlangga.

McGee, Harold. (2004). On Food and Cooking : The Science and Lore of The Kitchen. Scribner. United States of America.

Pahan, I. 2008. Panduan Lengkap Kelapa Sawit: Manajemen Agribisnis Dari Hulu hinggga Hilir. Cetakan kedua. Jakarta : Penebar Swadya.

Rangkuti, Freddy. 2004. Analisis SWOT : Teknik Membedah Kasus Bisnis Reorientasi Konsep Perencanaan Strategis untuk Menghadapi Abad 21. Jakarta : PT. Gramedia Pustaka Utama.

Reeves, James B.; Weihrauch, John L. 1979. Consumer and Food Economics Institute. Composition of foods: fats and oils. Agriculture handbook 8-4. Washington, D.C.: U.S. Dept. of Agriculture, Science and Education Administration. hlm. 4

Rizki, Januari, Nusril dan Putri Suci Asriani. 2014. Analisis Penanganan Penerimaan Tandan Buah Segar Pada PT. Bio Nusantara Teknologi Di Kecamatan Pondok Kelapa Kabupaten Bengkulu Tengah. Universitas Bengkulu.

Robinson, Pearce. 2008. Manajemen Stratejik Formulasi, Implementasi, dan Pengendalian Jilid 1. Jakarta: Binarupa Aksara.

Sukiyono Ketut, Indra Cahyadinata, Agus Purwoko, Septri Widiono, Eko Sumartono, Nyayu Neti Asriani and Gita Mulyasari. 2017. Assessing Smallholder Household Vulnerability to Price Volatility of Palm Fresh Fruit Bunch in Bengkulu Province. International Journal of Applied Business and Economic Research. 15(3): $1-15$.

Supranto, J. 2002. Statistik, Teori dan Aplikasi. Jakarta : Erlangga.

Tjiptono, Fandy. 2008. Service Management. Yogyakarta : Andi Offset.

Umar, Husein. 2005. Riset Pemasaran \& Perilaku Konsumen. Jakarta : Gramedia Pustaka Utama 